\title{
Detection Of Sliding Plane as A Disaster Mitigation Efforts In The Pengembur Village, Pujut Sub District, Central Lombok Regency
}

\author{
Baiq Ulfa Putri Elinda ${ }^{1}$, Hotinul Al Fatari ${ }^{2}$, Marzuki ${ }^{3}$, Bakti Sukrisna ${ }^{4}$, Alfina Taurida \\ Alaydrus $^{5}$, and Suhayat Minardi ${ }^{\text {** }}$ \\ ${ }^{1}$ Student of Physics Department, University of Mataram, Jalan Majapahit 62 Mataram 83125, Indonesia \\ ${ }^{2}$ Student of Physics Department, University of Mataram, Jalan Majapahit 62 Mataram 83125, Indonesia \\ ${ }^{3}$ Physics Department, University of Mataram, Jalan Majapahit 62 Mataram 83125, Indonesia \\ ${ }^{4}$ Physics Department, University of Mataram, Jalan Majapahit 62 Mataram 83125, Indonesia \\ ${ }^{5}$ Physics Department, University of Mataram, Jalan Majapahit 62 Mataram 83125, Indonesia \\ ${ }^{6}$ Physics Department, University of Mataram, Jalan Majapahit 62 Mataram 83125, Indonesia
}

( Received: May 14, 2018, Revised: September, 4, 2019, Accepted: January 21, 2020 )

\begin{abstract}
A landslide disaster is a threatening disaster every time coming of the rainy season. Landslide potency can be detected on the surface through the form of topography and vegetation and beneath the surface of the rock layers former. From the type of rock the former can be known existence of the sliding plane which is the place of the sliding material. Research has been conducted to detect the plane of slide based on the resistivity value and the shear wave speed by using geoelectric and seismic method in Pengembur village, sub district of Pujut, Central Lombok regency. The result of analysis shows that the rocks layer former in the area consist of low cohesion soil deposits, weathered clay soils, water-saturated sand, and unconsolidated sand which has a thickness $(3.7-4.0)$ meters. The field of sliding plane is detected as a layer of clay with landslides potency towards the west with the translation slide type
\end{abstract}

Keywords: landslide, sliding plane, translation slide, rock layer forming

\section{INTRODUCTION}

A landslide disaster is the move of rock masses down the slopes due to the disruption of the rock mass stability of the slope. Natural disasters, like a langslide, can cause loss of life, property, environmental damage, infrastructure, public facilities and the disruption of general public activities [1]. Factors which can trigger a landslide are categorized as external factors, including rainfall and earthquakes, and internal factors, covering the type of rock (litology) and diping of slopes [2].

An area is declared to have a potency of landslide when it has several features like diping slope that is quite steep, a layer under the surface of the ground that can not absorb water (impermeabel), rocks are not compact, rainfall with high intensity and the presence of weathering. Weathering has a significant influence in the determination of landslides [3]. This weathering material moves through a field called the sliding plane.

The sliding plane is a plane that holds water (low permeability) and usually consists of a hard layer and a soft layer. In the event of rain, the hard layer (waterproof) will become slippery and the soft layer will move through a tight coating so that a tight layer acting as a plane of slip and soft layer acts as a slide material [4].

The village of Pengembur is one of the villages in the district of Pujut, dominated by hills. This area has a diping slope of $5 \%$ to $15 \%\left(2.9^{\circ}\right.$ to $\left.8.5^{\circ}\right)$ and high intensity rainfall occurs in December to March. Based on the geological conditions of the area is composed of the old volcanic rock in the form breccia rock of lava rocks or tuffs that have undergone 
changes. The process of alteration on lava will produce clay material which can serve as a plane of slide [5].

Geophysical method as a tool to describe the state of the sub-surface can be used to achieve that goal. The Geoelectric method can distinguish the layers below the surface based on the value of the resistance type (resistivity). The method used in this study to obtain information on the variance of resistivity in $2 \mathrm{D}$ or $3 \mathrm{D}$ and this method has a high sensitivity to shallow exploration [6] and this method is also used to determine the plane of sliding based on reviewed from the resistivity value. To support the results of the interpretation of the geoelectric method, survey Refraction Mictrotremor (ReMi) was done at the same location. The ReMi method is a method that can record the propagation of waves beneath the surface with sourced from nature. This method is used because it has an excess of field operation more effective and has accuracy in detecting shallow surface layers [7].

\section{METHOD}

The study area is located in the village of Pengembur, sub district of Pujut, Central Lombok Regency (as shown in Figure 1) with the area of $30,360 \mathrm{~m}^{2}$. Data acquisition was conducted in March 2018.

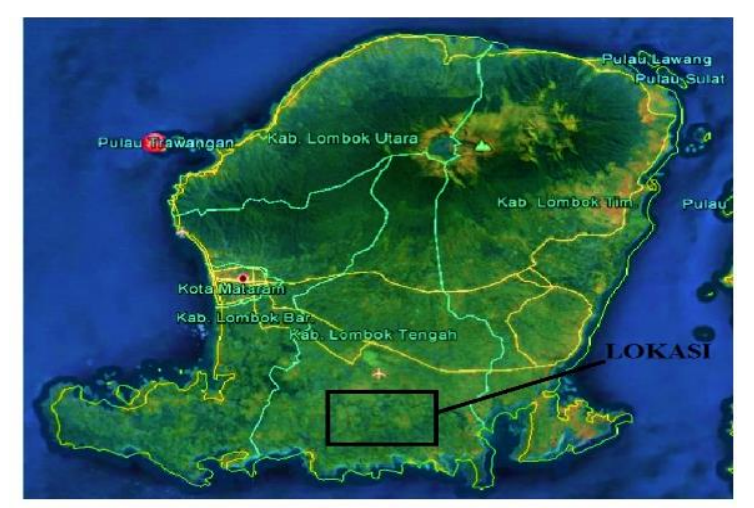

Figure 1. The study area at village of Pengembur, sub district of Pujut, Central Lombok Regency (not scaled) [8]

The measurement with the Geoelectric method is done on 6 lines and the ReMi method is 10 lines as shown in Figure 2. The coordinate position of each can be seen in Appendix 1.

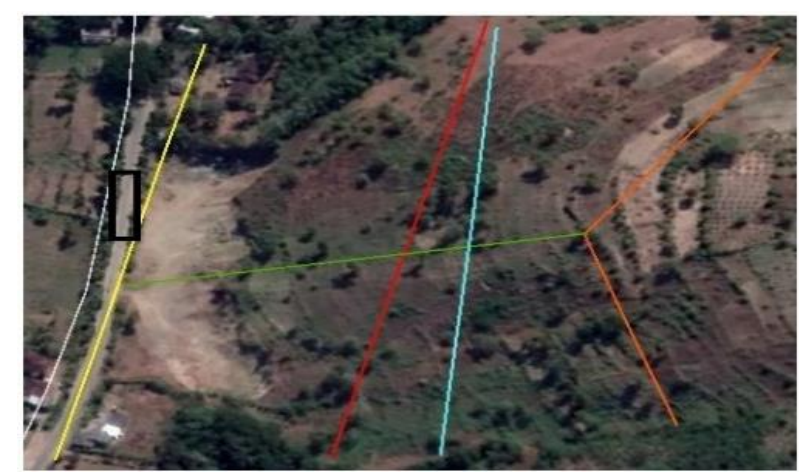

(a)

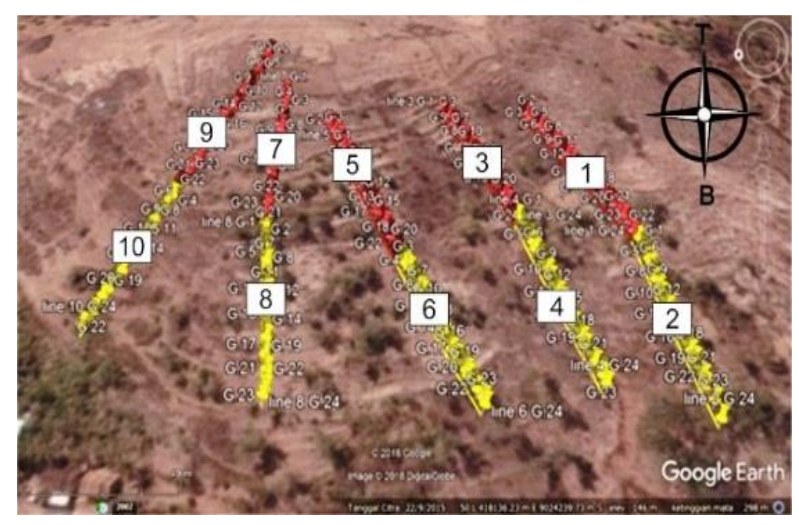

(b)

Figure 2 (a). Lines of geoelectrical method measurement, (b) Lines of ReMi method measurement

Geoelectric measurements use 1 set of G-Sound Resistivitymeter 4200 and for seismic measurement using a 24-channel PASI Seimometer (Figure 3). This research uses two simultaneous methods of geophysical, and data from both methods as materials for the analysis of the sliding plane and landslides in the research area. The research implementation stages are shown in Figure 4 below: 


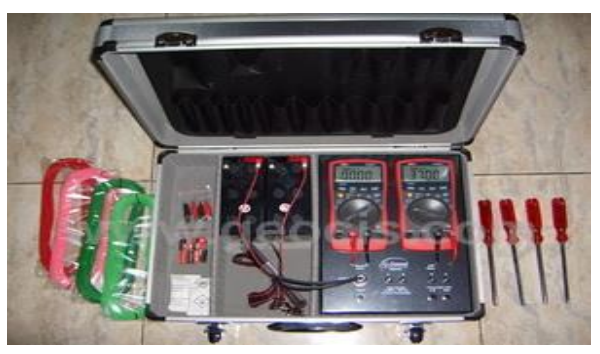

(a)

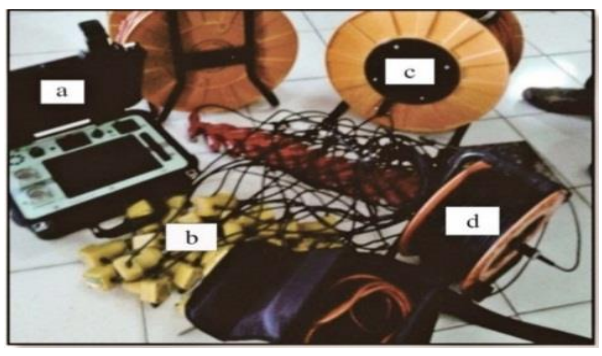

(b)

Figure 3. (a) G-Sound 4200 type Resistivitymeter [9]; (b) 24-channel PASI Seismometer [10]

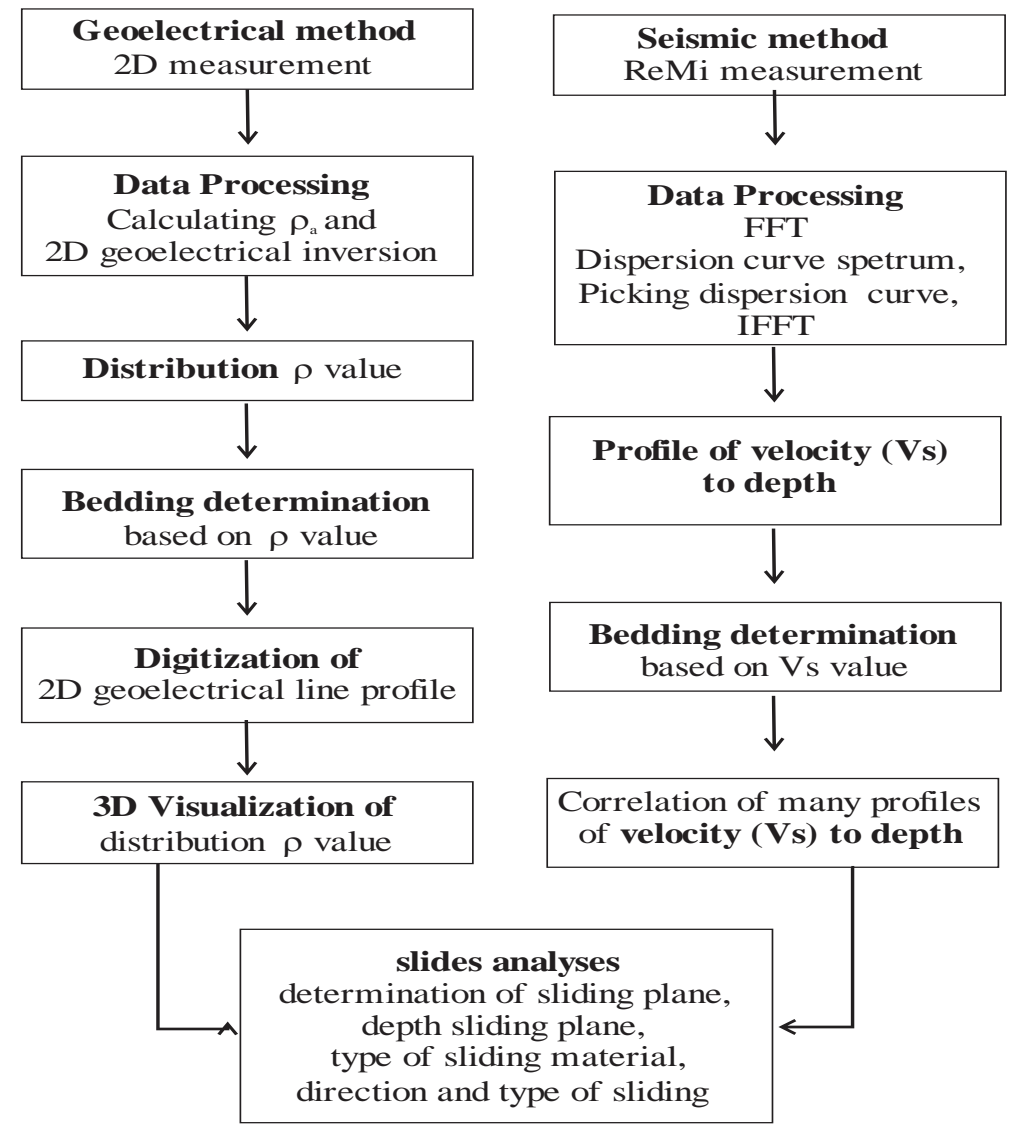

Figure 4. Stage of study of landside in Pengembur, sub district of Pujut, Central Lombok Regency

\section{RESULTS AND DISCUSSION}

The interpretation of geoelectric data is based on the results of inverse modeling of resistivity distribution. For example, as shown in Figure 5, are the results of the geoelectric inversion on line- 1 . At lane-1, which has a relatively north-south direction, is composed of 4 types of rock, as shown in table 1 . The sliding plane is in the third layer (marked by a dotted line in the black box) with a resistivity value of $14.00 \Omega \mathrm{m}$ up to $60.40 \Omega \mathrm{m}$ which is interpreted as clay stone and is at a depth of about $10.00 \mathrm{~m}$. The rock is an impermeable rock that cannot escape or absorb water, with the pile of sand and soil above the impermeable rock in the form of clay causing rainwater cannot seep deeper into the slope. Because rainwater that accumulates on the plane of slip (clay stone) will continue to press the grains of soil cover the slope and eventually can push the pile of soil to slip down. 


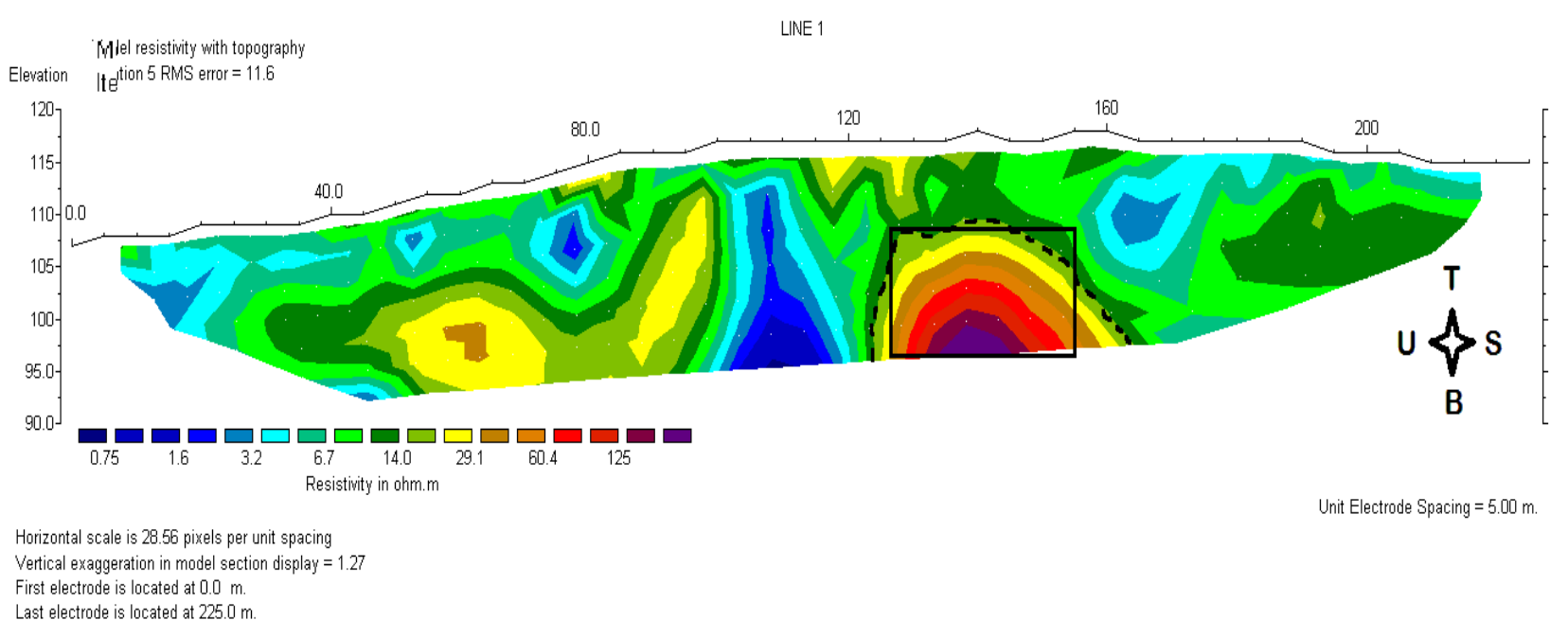

Figure 5. The 2D Resistivity section and sliding plane on Line-1

Tabel 1. Resistivity of rock as result of inversion under Line-1

\begin{tabular}{ccc}
\hline Resitivity value $\mathbf{( \Omega m})$ & Litologi & Depth $(\mathbf{m})$ \\
\hline $0,75 \leq \mathrm{R}<3,25$ & soil & $1,25 \leq \mathrm{h}<4,00$ \\
\hline $3,25 \leq \mathrm{R}<14,00$ & sand & $4,00 \leq \mathrm{h}<10,00$ \\
\hline $14,00 \leq \mathrm{R}<60,40$ & Claystone & $10,00 \leq \mathrm{h}<16,00$ \\
\hline $60,40 \leq \mathrm{R}<125,00$ & Wet Clay & $16,00 \leq \mathrm{h}<19,50$ \\
\hline
\end{tabular}

The rocks in the Pengembur Village are alterations from lava and tuff. The alteration process of subsurface lava rock will produce more and more clay minerals which will expand as time goes on [11]. This is consistent with the results of measurements that indicate the existence of a layer of clay stone and wet clay under a rock material that can escape water such as sand, so that the clay

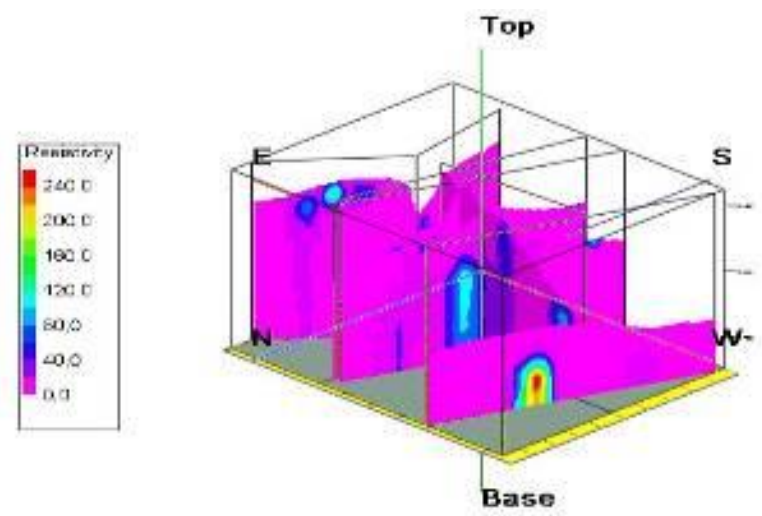

Figure 6. The results of vertical slicing of a solid 3D model appear from the north-west direction layer which tends to be slippery has the potential to become a sliding plane.

The 3D visualization, as shown in Figure 6 and Figure 7, is a 3D picture of dat gelistrik interpretation of 2D. This visualization is intended to give you an idea to give the distribution of rocks and the position of the sliding plane in the area of study.

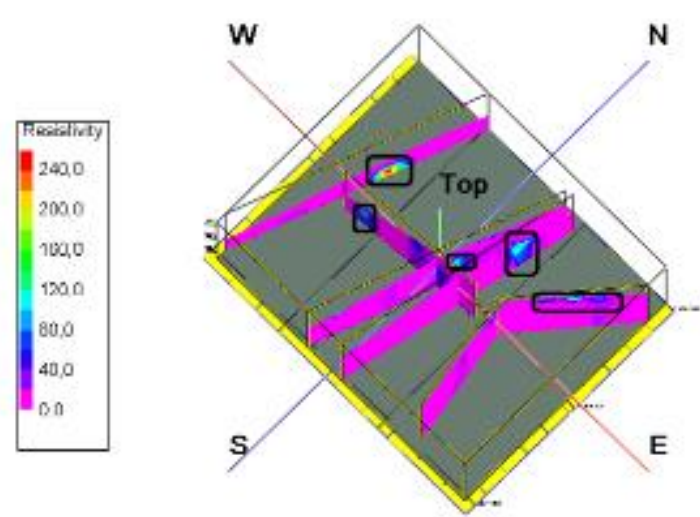

Figure 7. The results of vertical slicing of a solid 3D model appear above 
Figures 6 and 7 show that the silding plane is marked with a black box and were photographed with blue, red and yellow are in each path and spread from the East to the West. Based on the results of a solid data model, geological layers obtained research area based on litologi each trajectory looks North - West, as shown by Figure 8.

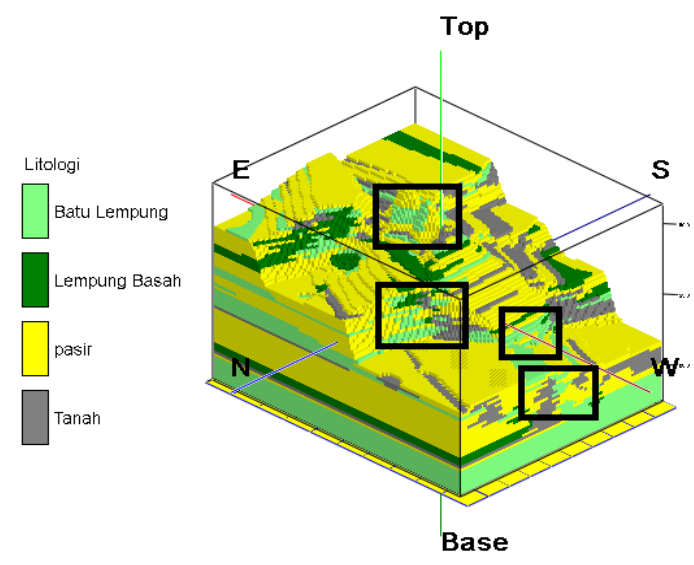

Figure 8 . The 3D visualization of geologic layer of the all geoelectrical line with sliding plane

Figure 8 shows the incompatibility of each layer of the soil. There are four types of rocks that forming layer of soil in the study area. Color light green illustrate the arrangement of the stone coating clays, color dark green describes the arrangement of layers of wet clay, color yellow describe sand and gray describes a layer of soil. Wet clay and clay stone is rock solid structure (waterproof) and mineral makeup of many stones, clays can also be interpreted as a type of sedimentary rock that is clay or plastis, composed of aluminum hidrous silicate (clay mineral) that the size of the fine details, while the wet clay is a layer of clay that has been saturated by the water. The sand is a rock material that can pass water and soil is the outermost layer of the Earth that was originally derived from the rocks that undergo weathering.

Based on the definition of the layers of rock that became known to the sliding plane. In General, a layer which consists of rocks that can skip over the water and the rocks of the watertight will potentially as sliding plane, such as the clay stone which is characterized by black box in Figure 8 . The sliding plane is identified as a layer of clay stone and the sliding material is identified as rock layers of sand that's can pass water. Type of mass wasting that occurs in is a translational slip that is heading west (towards the slope). Translated slip is the movement of soil mass on the plane of a flat slip or corrugated land, translational avalanches can also occur in the long term and are not realized because the movement of the landslide is very slow.

The lithology determination of the study area is also based on the value of the shear wave velocity, so that the thickness of the layer that is potentially prone to landslides is known. The results of data interpretation in the form of shear wave velocity profiles, as shown in Figure 9 and Figure 10, are shear wave velocity profiles on seismic line - 3 and 4. The results of interpretation of subsurface rock lithology based on the value of the shear wave velocity are shown in Table 2 .

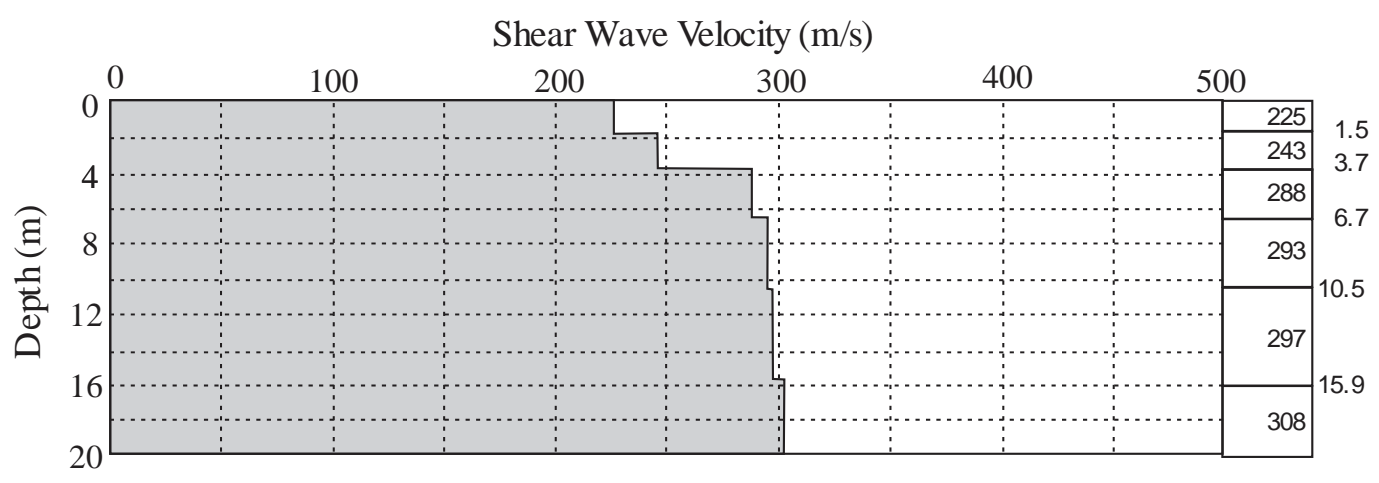

Figure 9. Shear Wave Velocity profile on the seismic line - 3 


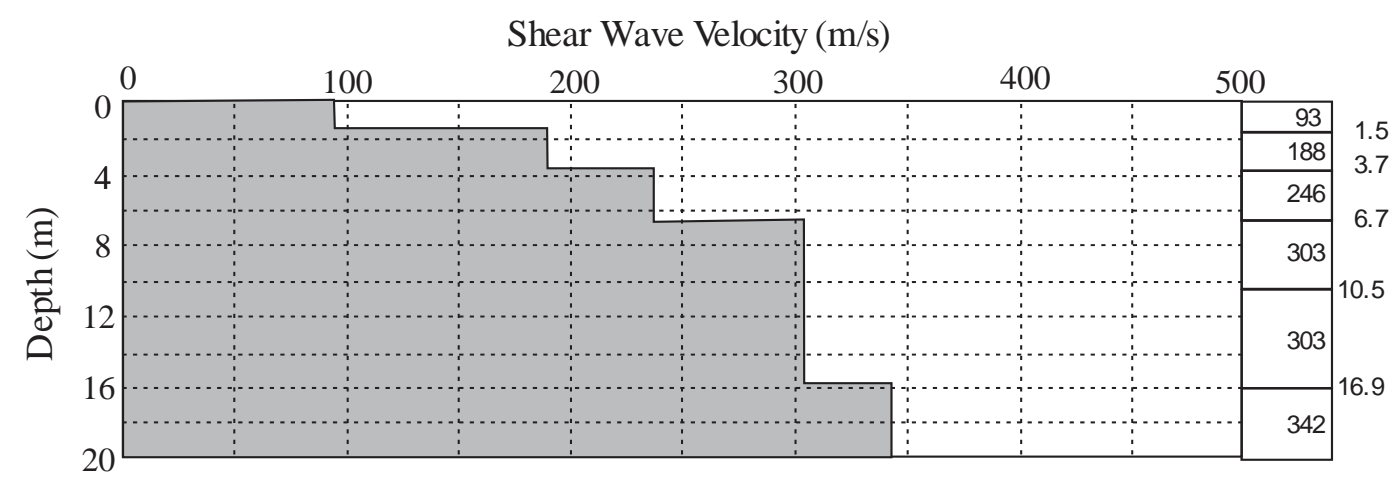

Figure 10. Shear Wave Velocity profile on the seismic line - 4

Table 2. Interpretation Results of The Subsurface Rock Litologi Based On Shear Wave Velocity Profiles on the seismic lines -3 and 4

\begin{tabular}{|c|c|c|c|c|c|c|}
\hline Line & Layer & $\begin{array}{c}\text { Layer } \\
\text { thickness } \\
(\mathbf{m})\end{array}$ & $\begin{array}{c}v_{s} \\
(\mathbf{m} / \mathbf{s})\end{array}$ & $\begin{array}{l}\% \\
\text { error }\end{array}$ & $\begin{array}{l}\text { Type of } \\
\text { Rock }\end{array}$ & Sediment \\
\hline \multirow{6}{*}{3} & 1 & 1,5 & 225 & \multirow{6}{*}{0,08} & \multirow{6}{*}{$\begin{array}{l}\text { medium } \\
\text { soil }\end{array}$} & \multirow{6}{*}{$\begin{array}{c}\text { Sand deposit and semi solid, gravel, } \\
\text { solid clay, water saturated sand, } \\
\text { unconsolidated sand }\end{array}$} \\
\hline & 2 & 2,2 & 243 & & & \\
\hline & 3 & 3 & 288 & & & \\
\hline & 4 & 3,8 & 293 & & & \\
\hline & 5 & 5,4 & 297 & & & \\
\hline & 6 & 4,1 & 308 & & & \\
\hline \multirow[b]{2}{*}{4} & 1 & 1,5 & 93 & \multirow[b]{2}{*}{0,54} & Soft soil & $\begin{array}{l}\text { soft clay, sand saturated by water, } \\
\text { unconsolidated sand }\end{array}$ \\
\hline & 2 & 2,2 & 188 & & $\begin{array}{l}\text { medium } \\
\text { soil }\end{array}$ & $\begin{array}{l}\text { Sand deposit semi solid, gravel, solid } \\
\text { clay, sand saturated by water, } \\
\text { unconsolidated sand }\end{array}$ \\
\hline
\end{tabular}

On seismic line 3 , there is a layer of rocks that is a layer of soil is being alleged in the form of deposits of semi-solid sand, gravel, solid clay, sand, water saturated sand, and unconsolidated sand. This layer has a thickness of 20 meters. Although type of soil layers are the same, but there is a difference of shear wave velocity variation value. Velocity has increasingly as a function of depth, this happens because of the deeper soil layers has more of compactness or more solid.

There are two layers of rock on seismic line 4, that is soft soil layers and layers of medium soil. The first layer of soft soil that is allegedly in the form of deposits of low to medium cohesive soils, soft clay, water saturated sand, and unconsolidated sand. A second layer of soil that is being alleged to consist of sand deposits and a semi solid, gravel, solid clay, water saturated sand, and unconsolidated sand. A similar layer found in the seismic line 5, 6, 7, 9, and 10 .

To illustrate and interpret the fields and material landslides, correlations are made between the lines as shown in Figure 11. 


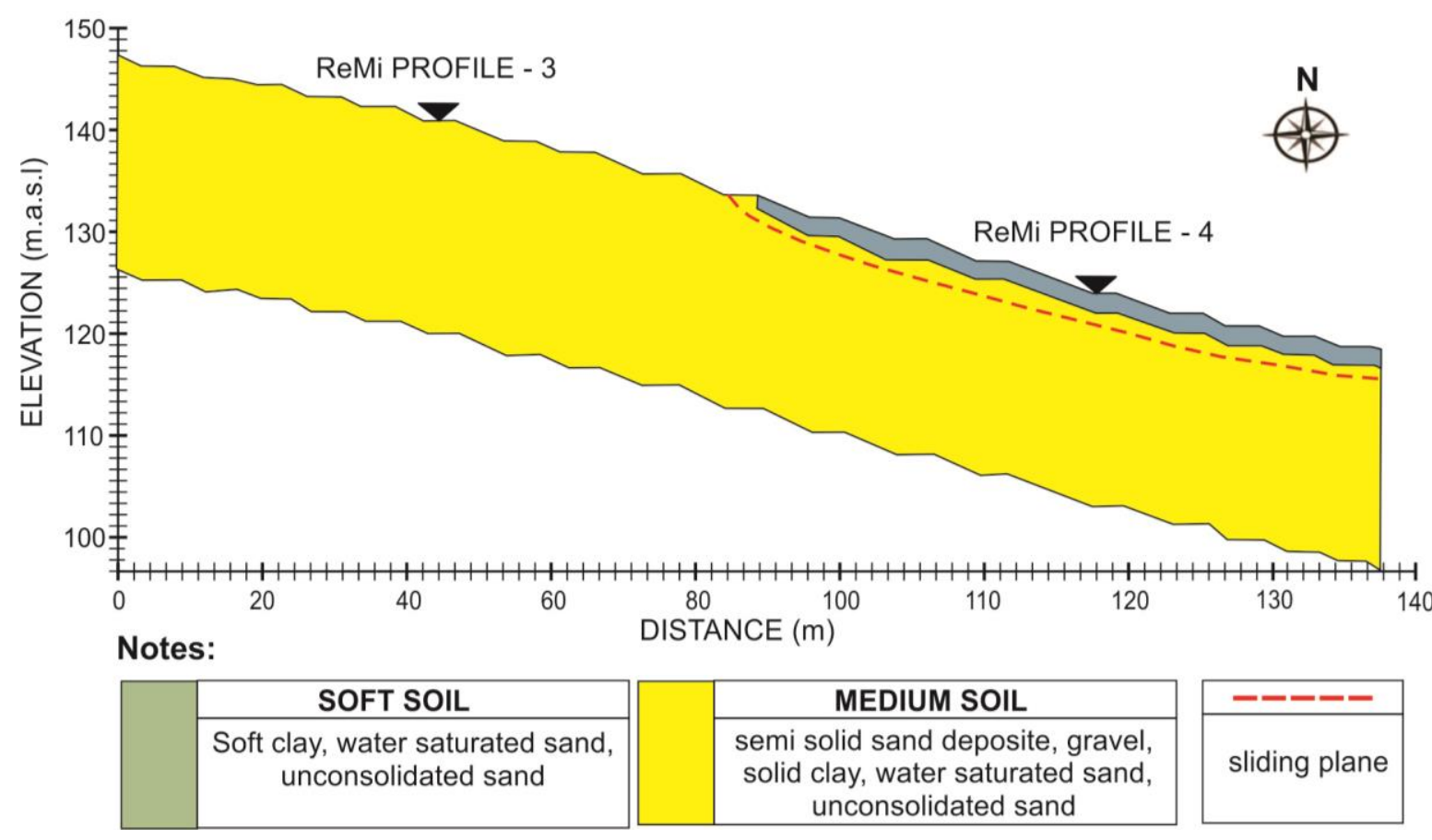

Figure 11. Interpretations of cross section of rock based on shear wave velocity profile on lines 3 and 4 which has a slope of $11.6^{\circ}$

Figure 11 shows that there is a potential for landslides in the study area as indicated by the results of identification of soft soil layers which are prone to landslides and are associated with factors causing landslides at the study site. Estimation of soft soil lithology which is a layer of landslide prone which is suspected to consist of low to moderate cohesion sediments, soft clay soil, water saturated sand, and unconsolidated sand. This soft soil layer is loose so that the sloping area of this layer will become sliding material. With the existence of low cohesion soil, the water can penetrate until the impermeable soil (medium soil) which later will act as a sliding plane, the soil becomes slippery and soft soil above which acts as a landslide material will move to follow the slope due to gravity and coupled with the factor of high rainfall in the study area that occurred in December to March.

In addition to land vegetation factors in the study area, it is also one of the triggers for landslides. The location is used as an agricultural area planted with plants with short roots (fibers) such as corn and shrubs. This results in the binding capacity of the soft soil at the roots so that the lithology which formed rocks in the form of low to moderate cohesive soil deposits, soft clay soil, water saturated sand, and unconsolidated sand are easily eroded downwards. Human activity in the form of mining in the area is a factor that increases the risk of landslides.

From the results of the interpretation of rock layers and slope, landslides that can occur at this research site are translation slides that occur on slides which are almost straight and parallel to the face of the land which can be seen in the crosssection interpretation of landslide-prone rock layers. This type of avalanche is expected to occur at each measurement of seismic line. However, of the ten seismic lines that have a negative impact in the event of a landslide is lane 9 and 110 that lead from east to west because there are settlements below the slope.

\section{CONCLUSION}

Based on the results of geoelectric and seismic data interpretation, can be concluded that the sliding plane is interpreted as a clay which has depth of about 4.00 meters. The sliding material in the the study area consists of soft soil deposits with low cohesion, weathered clay, water-saturated sand, and unconsolidated sand which has a thickness of 3.7 meters. With the visualization 3D detected the direction of landslide from east to west with an type of translations sliding. 


\section{ACKNOWLEDGMENT}

I want to say thank you to Agus Wahid Habiburrohman, S.Si. and Muhammad Al Faris, S.Si. for the helping and assistance during this study. The acknowledgments are also spoken to all parties who support to the completion of this study.

\section{REFERENCES}

[1] Sulaksana Nana and Inu ZainiYasir., 2013, Survey Geofisika Metode Resistivitas 2-D untuk Mitigasi Bencana Longsor di Lintasan Kereta Api Purwakarta Padalarang (in English : Geophysical Survey of 2-D Resistivity method for landslide disaster mitigation in Purwakarta Padalarang Railway). Bulletin of Scientific Contribution, Volume 11, No $3 \mathrm{Hal}$ 153-167.

[2] Caiyan, W U and Qiao Jianping. 2009. Relationship between landslides and lithology in the Three Gorges Reservoir Are Based on GIS and Information Value Model. Journal of Beijing Forestry University. Vol. 4 No. 2 Hal 165-170.

[3] Crozier, Michael J.1986. Lanslides: Causes Consequences and Environment. Croom Helm. London.

[4] Dona, Irepia Refa. 2015. Identifikasi Bidang Gelincir Menggunakan Metode Geolistrik Tahanan Jenis Konfigurasi Schlumberger di Bukit Lantiak Kecamatan Padang Selatan (in English:. Identification of the sliding plane using a resistivity method Schlumberger configuration at Bukit Lantiak South Padang subdistrict), Universitas Negeri Padang.
[5] Badan Pusat Statistika Kabupaten Lombok Tengah. 2017. Kecamatan Pujut dalam Angka. Koordinator Statistik Kecamatan Pujut.

[6] Reynolds, J.M. 1997. An Introduction to Applied and Environmental Geophysics. New York: Jhon Geophysicsin Hidrogeological and Wiley and Sons Ltd.

[7] Nausil, Syamsuddin, Rustan Efendi, dan Sandra. 2015. Penentuan Struktur Batuan Daerah Rawan Longsor menggunakan Metode Seismik Mikrotremor di Desa Enu Kecamatan Sindue Kabupaten Donggala (in English : Regional rock structures determination in landslides area using seismic Microtremor method in Enu village Sindue District Donggala). Palu: Universitas Tadulako.

[8] (www.google.com/earth)

[9] http://geocis.net/page.php?G-Sound

[10] http://ritmindustry.com/catalog/geophonesseismographs/exploration-seismograph-1224-channel-data-acquisition-24-bit/

[11] Darmawan, Alwin., 2009, Identifikasi Proses Terjadinya Gerakan Tanah Di Kawasan Bandung Utara Melalui Pendekatan Fasies Gunung Api : Studi Kasus Desa Cihideung, Kecamatan Parongpong, Kabupaten Bandung Barat, Jawa Barat (in English: Identifification of of land movement process in the area of North Bandung through the Volcano Fasies approach: The case study of Cihideung village, Parongpong District, West Bandung Regency, West Java), Buletin Geologi Tata Lingkungan, Vol. 19 No. 1, Hal. 9-19. 


\section{APPENDIX}

Coordinate of line geoelectrical measurement

\begin{tabular}{llllll}
\hline \multirow{2}{*}{ No. } & Identity & \multicolumn{4}{c}{ Latitude/Longitude } \\
\cline { 2 - 6 } & & \multicolumn{2}{c}{ Start } & \multicolumn{2}{c}{ End } \\
\hline $\mathbf{1}$ & Line 1 & $8^{\circ} 49^{\prime} 40.26^{\prime \prime} \mathrm{S}$ & $116^{\circ} 15^{\prime} 13.31^{\prime \prime} \mathrm{E}$ & $8^{\circ} 49^{\prime} 33.31^{\prime \prime} \mathrm{S}$ & $116^{\circ} 15^{\prime} 15.85^{\prime \prime} \mathrm{E}$ \\
\hline $\mathbf{2}$ & Line 2 & $8^{\circ} 49^{\prime} 40.51^{\prime \prime} \mathrm{S}$ & $116^{\circ} 15^{\prime} 16.31^{\prime \prime} \mathrm{E}$ & $8^{\circ} 49^{\prime} 33.39^{\prime \prime} \mathrm{S}$ & $116^{\circ} 15^{\prime} 18.86^{\prime \prime} \mathrm{E}$ \\
\hline $\mathbf{3}$ & Line 3 & $8^{\circ} 49^{\prime} 40.52^{\prime \prime} \mathrm{S}$ & $116^{\circ} 15^{\prime} 17.48^{\prime \prime} \mathrm{E}$ & $8^{\circ} 49^{\prime} 33.50^{\prime \prime} \mathrm{S}$ & $116^{\circ} 15^{\prime} 18.90^{\prime \prime} \mathrm{E}$ \\
\hline $\mathbf{4}$ & Line 4 & $8^{\circ} 49^{\prime} 40.21^{\prime \prime} \mathrm{S}$ & $116^{\circ} 15^{\prime} 19.85^{\prime \prime} \mathrm{E}$ & $8^{\circ} 49^{\prime} 34.32^{\prime \prime} \mathrm{S}$ & $116^{\circ} 15^{\prime} 21.62^{\prime \prime} \mathrm{E}$ \\
\hline $\mathbf{5}$ & Line 5 & $8^{\circ} 49^{\prime} 37.39^{\prime \prime} \mathrm{S}$ & $116^{\circ} 15^{\prime} 14.48^{\prime \prime} \mathrm{E}$ & $8^{\circ} 49^{\prime} 37.04^{\prime \prime} \mathrm{S}$ & $116^{\circ} 15^{\prime} 19.27^{\prime \prime} \mathrm{E}$ \\
\hline
\end{tabular}

Coordinate of line seismic measurement

\begin{tabular}{|c|c|c|c|c|c|}
\hline \multirow{3}{*}{$\begin{array}{c}\text { No } \\
\text { • }\end{array}$} & \multirow[t]{2}{*}{ Identity } & \multicolumn{4}{|c|}{ Latitude/Longitude } \\
\hline & & \multicolumn{2}{|c|}{ Start } & \multicolumn{2}{|c|}{ End } \\
\hline & Line 1 & $8^{\circ} 49^{\prime} 40.47^{\prime \prime} \mathrm{S}$ & $116^{\circ} 15^{\prime} 17.46^{\prime \prime} \mathrm{E}$ & $8^{\circ} 49^{\prime} 39.69^{\prime \prime} \mathrm{S}$ & $116^{\circ} 15^{\prime} 19.62^{\prime \prime} \mathrm{E}$ \\
\hline 2 & Line 2 & $8^{\circ} 49^{\prime} 40.47^{\prime \prime} \mathrm{S}$ & $116^{\circ} 15^{\prime} 17.46^{\prime \prime} \mathrm{E}$ & $8^{\circ} 49^{\prime} 40.43^{\prime \prime} \mathrm{S}$ & $116^{\circ} 15^{\prime} 15.13^{\prime \prime} \mathrm{E}$ \\
\hline 3 & Line 3 & $8^{\circ} 49^{\prime} 38.55^{\prime \prime} \mathrm{S}$ & $116^{\circ} 15^{\prime} 19.85^{\prime \prime} \mathrm{E}$ & $8^{\circ} 49^{\prime} 39.07 " \mathrm{~S}$ & $116^{\circ} 15^{\prime} 17.95^{\prime \prime} \mathrm{E}$ \\
\hline 4 & Line 4 & $8^{\circ} 49^{\prime} 39.07^{\prime \prime} \mathrm{S}$ & $116^{\circ} 15^{\prime} 17.95^{\prime \prime} \mathrm{E}$ & 849'39.36" S & $116^{\circ} 15^{\prime} 15.73^{\prime \prime} \mathrm{E}$ \\
\hline 5 & Line 5 & $8^{\circ} 49^{\prime} 36.89^{\prime \prime} \mathrm{S}$ & $116^{\circ} 15^{\prime} 19.76^{\prime \prime} \mathrm{E}$ & $8^{\circ} 49^{\prime} 37.41 " \mathrm{~S}$ & $116^{\circ} 15^{\prime} 17.69^{\prime \prime} \mathrm{E}$ \\
\hline 6 & Line 6 & $8^{\circ} 49^{\prime} 37.41^{\prime \prime} \mathrm{S}$ & $116^{\circ} 15^{\prime} 17.69^{\prime \prime} \mathrm{E}$ & $8^{\circ} 49^{\prime} 37.96 " \mathrm{~S}$ & $116^{\circ} 15^{\prime} 15.76^{\prime \prime} \mathrm{E}$ \\
\hline 7 & Line 7 & $8^{\circ} 49^{\prime} 36.39^{\prime \prime} \mathrm{S}$ & $116^{\circ} 15^{\prime} 20.46^{\prime \prime} \mathrm{E}$ & $8^{\circ} 49^{\prime} 35.88^{\prime \prime} \mathrm{S}$ & $116^{\circ} 15^{\prime} 18.48^{\prime \prime} \mathrm{E}$ \\
\hline 8 & Line 8 & $8^{\circ} 49^{\prime} 35.88^{\prime \prime} \mathrm{S}$ & $116^{\circ} 15^{\prime} 18.48^{\prime \prime} \mathrm{E}$ & $8^{\circ} 49^{\prime} 35.65^{\prime \prime} \mathrm{S}$ & $116^{\circ} 15^{\prime} 16.36^{\prime \prime} \mathrm{E}$ \\
\hline 9 & Line 9 & $8^{\circ} 49^{\prime} 35.92^{\prime \prime} \mathrm{S}$ & $116^{\circ} 15^{\prime} 21.17^{\prime \prime} \mathrm{E}$ & $8^{\circ} 49^{\prime} 34.90^{\prime \prime} \mathrm{S}$ & $116^{\circ} 15^{\prime} 19.40^{\prime \prime} \mathrm{E}$ \\
\hline 10 & Line 10 & $8^{\circ} 49^{\prime} 34.90^{\prime \prime} \mathrm{S}$ & $116^{\circ} 15^{\prime} 19.40^{\prime \prime} \mathrm{E}$ & $8^{\circ} 49^{\prime} 33.73^{\prime \prime} \mathrm{S}$ & $116^{\circ} 15^{\prime} 17.70^{\prime \prime} \mathrm{E}$ \\
\hline
\end{tabular}

